\title{
RICE COLD TOLERANCE AT THE REPRODUCTIVE STAGE IN A CONTROLLED ENVIRONMENT
}

\author{
Renata Pereira da Cruz ${ }^{1 *}$; Sandra Cristina Kothe Milach²; Luiz Carlos Federizzi ${ }^{3}$

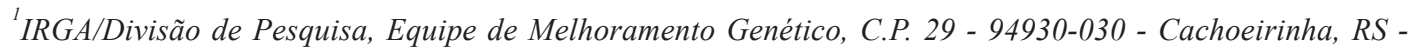 \\ Brasil. \\ ${ }_{3}^{2}$ Pioneer Sementes - Paissandú, C.P. 582 - 99010-080 - Passo Fundo, RS - Brasil. \\ ${ }^{3}$ UFRGS/FA - Dep. de Plantas de Lavoura, C.P. 776 - 91501-970 - Porto Alegre, RS - Brasil. \\ *Corresponding author <rpdacruz@hotmail.com>
}

\begin{abstract}
Cold tolerance of rice (Oryza sativa L.) during the reproductive stage is important to guarantee high yield under low temperature environments. Field selection, however, does not allow identification of adequate tolerance sources and limits selection of segregating lines due to variable temperature. The objective of this study was to devise methods for distinguishing rice genotypes as to their cold tolerance at the reproductive stage when evaluated under controlled temperature. The effect of cold temperatures was investigated in six rice genotypes at $17^{\circ} \mathrm{C}$ for varying length of time (three, five, seven and ten days) at two reproductive stages (microsporogenesis and anthesis). Cold tolerance was measured as the percentage of reduction in panicle exsertion and in spikelet fertility. Evaluating cold tolerance through the reduction in panicle exsertion did not allow for the distinction between cold tolerant from cold sensitive genotypes and, when the reduction in spikelet fertility was considered, a minimum of seven days was required to differentiate the genotypes for cold tolerance. Genotypes were more sensitive to cold at anthesis than at microsporogenesis and, as these stages were highly correlated, cold screening could be performed at anthesis only, since it is easier to determine. Rice cold tolerance at the reproductive stage may be characterized by the reduction in spikelet fertility due to cold temperature $\left(17^{\circ} \mathrm{C}\right)$ applied for seven days at anthesis.
\end{abstract}

Key words: cold temperature, microsporogenesis, anthesis, panicle exsertion, spikelet sterility

\section{TOLERÂNCIA AO FRIO DO ARROZ NO ESTÁDIO REPRODUTIVO SOB CONDIÇÕES CONTROLADAS}

\begin{abstract}
RESUMO: A tolerância do arroz (Oryza sativa L.) ao frio no período reprodutivo é importante para garantir alto rendimento em ambientes com temperatura baixa. No entanto, a seleção em condições de campo não permite identificar fontes adequadas de tolerância e limita a seleção de linhas segregantes devido à temperatura variável. Este trabalho teve por objetivo definir uma metodologia capaz de distinguir genótipos de arroz quanto à sua tolerância ao frio no período reprodutivo quando avaliados sob temperatura controlada. $\mathrm{O}$ efeito do frio foi investigado em seis genótipos de arroz submetidos a $17^{\circ} \mathrm{C}$ por períodos variáveis de tempo (três, cinco, sete e dez dias) em dois estádios do período reprodutivo (microsporogênese e antese). A tolerância ao frio foi avaliada por meio da porcentagem de redução na exerção da panícula e na fertilidade de espiguetas. O resultados indicaram que avaliar a tolerância ao frio por meio da redução na exerção da panícula não permitiu separar genótipos tolerantes ao frio de genótipos sensíveis e, quando avaliada por meio da redução na fertilidade de espiguetas, no mínimo sete dias foram necessários para diferenciar os genótipos quanto à tolerância ao frio. Eles foram mais sensíveis ao frio na antese que na microsporogênese e, como estes estádios foram altamente correlacionados, a seleção sob frio poderia ser feita somente neste estádio, que é de mais fácil determinação. Logo, a tolerância do arroz ao frio no período reprodutivo pode ser avaliada por meio da redução na fertilidade de espiguetas devido à temperatura baixa $\left(17^{\circ} \mathrm{C}\right)$ aplicada por sete dias no estádio de antese.

Palavras-chave: temperatura baixa, microsporogênese, antese, exerção da panícula, esterilidade de espiguetas
\end{abstract}

\section{INTRODUCTION}

Low temperature during the reproductive stage in rice causes degeneration of spikelets, incomplete panicle exsertion and increases spikelet sterility (Terres, 1991), thus reducing grain yield. In Rio
Grande do Sul State (RS), southern Brazil, cold temperature occurs once every three years, causing yield losses in excess of $25 \%$ (Terres \& Galli, 1985). This is also a serious problem in many other countries, such as Japan, China, Chile, USA and Australia (Futsuhara \& Kikuchi, 1984; Alvarado \& Grau, 1991; Guorui, 
1991; Tilquin \& Detry, 1993; McKenzie et al., 1994). Despite the importance of cold tolerance, breeding for this trait in RS has been conducted mainly under field conditions and this has led to limited genetic progress due to variable temperature and differences in maturity among breeding lines, leading to low selection pressure. Evaluation of genotypes under controlled conditions seems to be the only way to get a consistent characterization of cold tolerance.

Several screening procedures have been described for evaluating cold tolerance under controlled environment, which employ a range of air temperatures from 10 to $20^{\circ} \mathrm{C}$ (Lin \& Peterson, 1975; Lee, 1979; Khan et al., 1986; Andaya \& Mackill, 2003; Gunawardena et al., 2003) or cold water $\left(19^{\circ} \mathrm{C}\right)$ for the screening (Saito et al., 2001; 2003; 2004; Takeuchi et al., 2001). A simple method that allows for an objective evaluation of rice genotypes to low temperatures manipulated in the local breeding programs might make the selection process easier and less costly. Factors such as genotype, temperature stress (intensity and duration of exposure), phase of the reproductive stage, and the interaction among them must be considered when defining a screening method. In this context, the objective of the present study was to identify a method for the characterization of six rice genotypes in terms of cold tolerance at the reproductive stage.

\section{MATERIAL AND METHODS}

Six rice genotypes were studied (Table 1), which were expected to differ as to their cold tolerance at the reproductive stage, with the Japonica genotypes being tolerant and the Indica being sensitive.

\section{Conduction of the experiment}

The experiment was conducted in a greenhouse at Cachoeirinha, RS (29 57'04's and $\left.51^{\circ} 05^{\prime} 38^{\prime \prime} \mathrm{O}\right)$. Seeds were directCly sown in plastic pots $(19.5 \times 16 \mathrm{~cm})$ containing soil collected in the experimental field and fertilized with $2 \mathrm{~g}$ of NPK (2-2020 ). The number of pots per genotype was 30 and, 20 days after sowing; each pot was thinned to three plants per pot. Nitrogen fertilization was applied 40 days after emergence using $2 \mathrm{~g}$ of urea $(45 \% \mathrm{~N})$ per pot.

Plants were kept in the greenhouse at $28^{\circ} \mathrm{C}$ and when one or more tillers in a pot reached one of the two reproductive stages (microsporogenesis or anthesis), it was individually labeled as to its reproductive stage and the whole plant was taken to an artificially lighted room where the cold temperature treatment was initiated. This room had a constant temperature of $17^{\circ} \mathrm{C}$ and a photoperiod of $9 \mathrm{~h} / 15 \mathrm{~h}$ and, after cold exposure (three, five, seven and ten days), the pots were taken back to the greenhouse. Light in the cold room was provided by fluorescent and incandescent lamps and corresponded to $1517.7 \mu \mathrm{mol} \mathrm{s}^{-1} \mathrm{~m}^{-2}$. Differences in light intensity and quality between the cold room and the greenhouse were an uncontrolled variable, since in the latter the radiation source was the sun. For each genotype, some plants were kept permanently in the greenhouse, as the control treatment.

At maturation each labeled tiller had its panicle individually harvested and evaluated for the degree of panicle exsertion and percentage of spikelet fertility. Degree of panicle exsertion was measured as the relative distance from the flag leaf ligule to the panicle ciliar node. Positive and negative values indicate complete (flag leaf ligule below the panicle ciliar node) and incomplete panicle exsertion (flag leaf ligule above the panicle ciliar node), respectively. Percentage of spikelet fertility was obtained by counting the number of filled and empty spikelets and expressed as percentage of filled spikelets in relation to the total number of spikelets in the panicle.

\section{Determination of the reproductive stage}

Microsporogenesis was determined by the distance between the ligule of the flag leaf and that of the penultimate leaf (Yoshida, 1981), considering an interval of -3 (flag leaf ligule below the penultimate leaf ligule) to $+10 \mathrm{~cm}$ (flag leaf ligule above the penultimate leaf ligule) as the indicative of this stage (Figure 1). Maximum microsporogenesis may vary, however, within this range, depending on the genotype. In some genotypes it may take place at $-3 \mathrm{~cm}$, in oth-

Table 1 - Genealogy, country of origin and subspecies of the six rice genotypes evaluated for cold tolerance at the reproductive period.

\begin{tabular}{|c|c|c|c|}
\hline Genotype & Genealogy & Country of origin & Subspecies \\
\hline Quilla 64117 & Delta/Oro & Chile & Japonica \\
\hline Quilla 66304 & Cesariot/Oro & Chile & Japonica \\
\hline Diamante & Agostano/P6//Blue Rose/RB2/Balilla & Chile & Japonica \\
\hline IRGA 417 & New Rex/IR19743-25-2-2//BR-IRGA 409 & Brazil & Indica \\
\hline BRS 7 & Unknown & Brazil & Indica \\
\hline IR 8 & Peta/Dee-Geo-Woo-Gen & Philippines & Indica \\
\hline
\end{tabular}



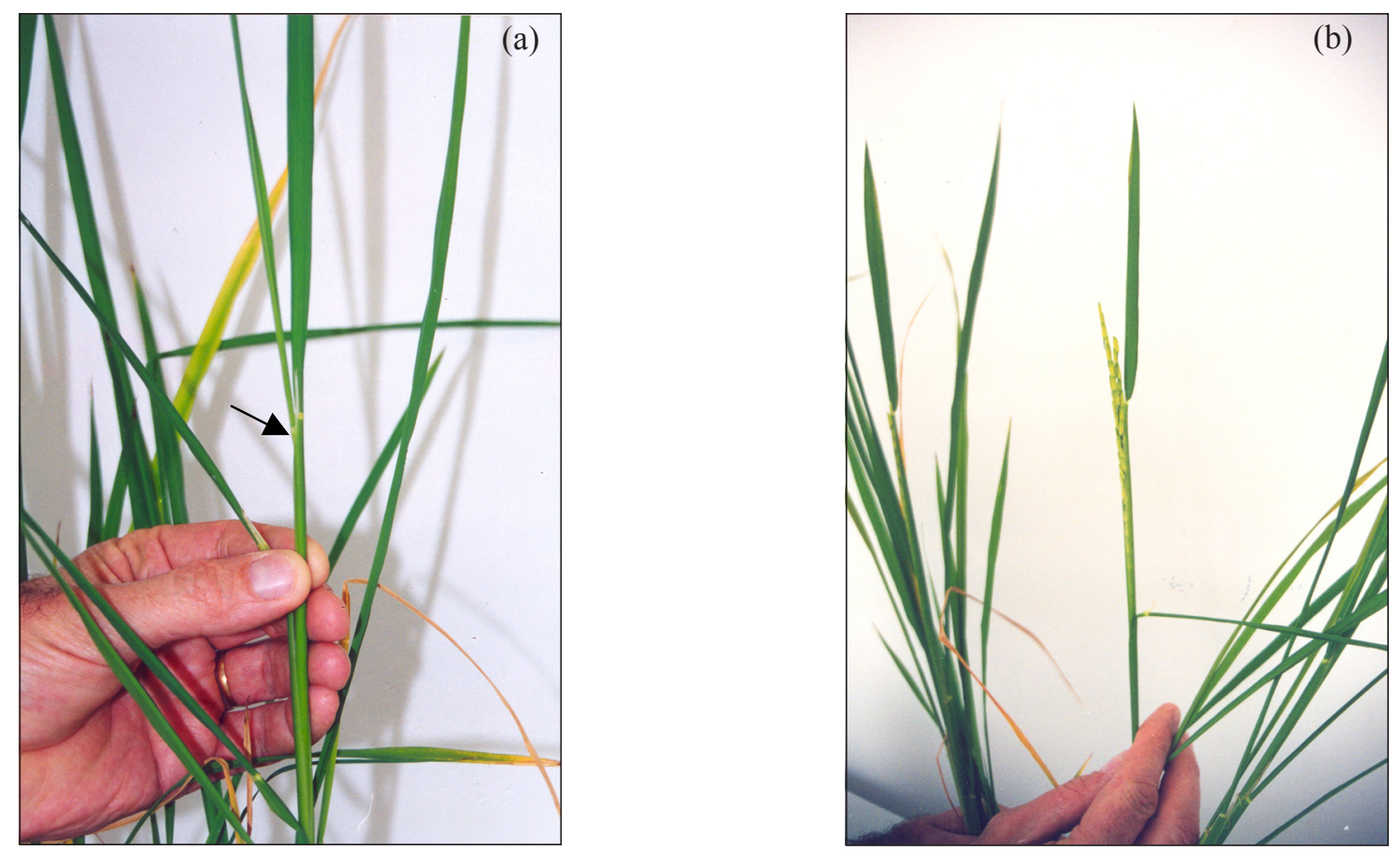

Figure 1 - Tiller at the microsporogenesis (a) and at the anthesis (b) stages. The tiller in (a) shows a distance between the flag leaf auricle and the penultimate one of $-1 \mathrm{~cm}$ (arrow).

ers at zero, and in others at $+8 \mathrm{~cm}$. To avoid this in the present study, an equal number of tillers were taken for each value in the range -3 to $+10 \mathrm{~cm}$ in each genotype, so this interval would be equally represented in each of them.

Anthesis was considered as the beginning of panicle exposure (Figure 1) and, in the case of flowers already open, they were manually removed.

\section{Treatments, experimental design and statistical analysis}

Experimental design was completely randomized, with a variable number of replications, which corresponded to the number of tillers evaluated in each treatment. The treatments consisted of combinations among levels of the three factors studied: genotype, reproductive stage and duration of exposure to cold, in a $6 \times 2 \times 4$ factorial.

For each genotype, traits measured under the cold treatment were expressed as percentage of reduction in relation to the control, which represented the mean value of the traits measured in the genotypes kept in the greenhouse.

Residual and regression analysis were performed to verify data normality and the need for transformation, respectively, and based on them percentage of reduction in panicle exsertion had to be transformed by the $\sqrt{ }(x+10)$. The analysis of variance was performed considering a factorial experiment in the completely randomized design with fixed effects for the factors, using the GLM (general linear model) procedure of SAS (SAS Institute, 2000). Means were compared by the Tukey-Kramer method $(P<0.05)$, due to the different number of replications per treatment.

Linear regression analysis was performed for the factor duration of exposure to cold, in order to verify the behavior of panicle exsertion and spikelet fertility in relation to the increase in cold temperature exposure. Five levels were used: three, five, seven and ten days of cold exposure and the level zero, which corresponded to the control.

Pearson's coefficients of correlation were obtained in order to verify the correlations between the two traits in each stage and the correlations between the two stages. All the analysis were performed in the Statistical Analysis System (SAS Institute, 2000).

\section{RESULTS}

The main effects of the factors studied as well as the first and second order interactions were highly significant for the two traits (Table 2), indicating that genotype, reproductive stage and duration of cold exposure differed for the percentage of reduction in panicle exsertion and in spikelet fertility under $17^{\circ} \mathrm{C}$. The significance of the second order interaction indicates that each factor was distinctly affected by the levels of the other two factors and vice-versa. For this reason, the traits were studied considering all the levels of the three factors simultaneously. 


\section{Percentage of reduction in panicle exsertion}

The high reduction in panicle exsertion, more than $100 \%$ (Table 3 ), is due to the fact that this trait exhibited both positive and negative values, which corresponded to complete and incomplete exsertion, respectively. Thus a reduction in the degree of panicle exsertion from $+2 \mathrm{~cm}$ in the control treatment, for example, to $-2 \mathrm{~cm}$, due to cold temperature, would mean a reduction of $200 \%$. This also explains the higher coefficient of variation $(\mathrm{CV})$ associated with this trait (Table 2).

In all durations of cold exposure, reduction in panicle exsertion was generally, larger at anthesis than at microsporogenesis (Table 3). The only exception was Quilla 64117, in which reduction in panicle exsertion was observed only at microsporogenesis (Table 3).

There was no clear distinction between cold tolerant and sensitive genotypes in regard to reduction in panicle exsertion in any of the stages and durations of cold exposure (Table 3). The sensitive genotype IR 8 showed the largest reduction in this trait, differing from the others in all durations of cold exposure and stages (Table 3).

All genotypes showed the largest reduction in panicle exsertion with ten days of exposure to cold,

Table 2 - Mean squares for the two traits evaluated in six rice genotypes submitted to four durations of cold exposure at two stages of the reproductive period.

\begin{tabular}{lrcc}
\hline Source of variation & DF & Reduction in panicle exsertion & Reduction in spikelet fertility \\
\hline Genotype & 5 & $891.5^{* *}$ & $20396.8^{* *}$ \\
Stage & 1 & $1081.4^{* *}$ & $8305.6^{* *}$ \\
Duration & 3 & $77.5^{*}$ & $11450.3^{* *}$ \\
Genotype $\times$ stage & 5 & $47.3^{* *}$ & $1681.4^{* *}$ \\
Genotype $\times$ duration & 14 & $12.3^{* *}$ & $816.2^{* *}$ \\
Stage $\times$ duration & 3 & $16.5^{* *}$ & $902.4^{* *}$ \\
Genotype $\times$ stage $\times$ duration & 13 & $11.2^{*}$ & $639.7^{* *}$ \\
Error & $a$ & 4.9 & 37.0 \\
\hline $\mathrm{CV}(\%)$ & & 20.9 & 1.2 \\
$\mathrm{R}^{2}$ & & 0.9 & 0.98 \\
\hline $\mathrm{De}$ & & & \\
\hline
\end{tabular}

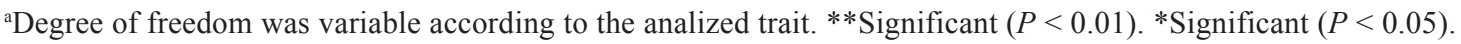

Table 3 - Means for percentage of reduction in panicle exsertion of six rice genotypes submitted to four cold temperature $\left(17^{\circ} \mathrm{C}\right)$ durations at two stages of the reproductive period.

\begin{tabular}{lcccc}
\hline Genotype & \multicolumn{3}{c}{ Microsporogenesis } \\
\cline { 2 - 5 } & 3 days & 5 days & 7 days & 10 days \\
\hline Quilla64117 & $0 \mathrm{cB}$ & $-1 /$ & $50 \mathrm{bA}$ & $55 \mathrm{bA}^{*}$ \\
Quilla66304 & $14 \mathrm{bA}^{*}$ & - & $9 \mathrm{bA}^{*}$ & $24 \mathrm{bA}^{*}$ \\
Diamante & $0 \mathrm{cB}^{*}$ & $9 \mathrm{bB}^{*}$ & $32 \mathrm{bAB}^{*}$ & $80 \mathrm{bA}^{*}$ \\
IR 8 & $168 \mathrm{aC}^{*}$ & $332 \mathrm{aB}^{*}$ & $443 \mathrm{aAB}$ & $540 \mathrm{aA}^{*}$ \\
IRGA 417 & $5 \mathrm{cB}^{*}$ & $3 \mathrm{bB}^{*}$ & $7 \mathrm{bB}^{*}$ & $45 \mathrm{bA}^{*}$ \\
BRS 7 & $7 \mathrm{cB}^{*}$ & $17 \mathrm{bB}^{*}$ & $47 \mathrm{bAB}^{*}$ & $91 \mathrm{bA}^{*}$ \\
\hline Genotype & & & Anthesis & 10 days \\
\hline Quilla64117 & 3 days & 5 days & 7 days & 0 dA \\
Quilla66304 & $0 \mathrm{cdA}$ & - & $0 \mathrm{dA}$ & $148 \mathrm{bcA}$ \\
Diamante & $64 \mathrm{cA}$ & $95 \mathrm{bA}$ & $123 \mathrm{bcA}$ & $718 \mathrm{bA}$ \\
IR 8 & $127 \mathrm{bcAB}$ & $97 \mathrm{bB}$ & $653 \mathrm{aA}$ & $129 \mathrm{cA}$ \\
IRGA 417 & $509 \mathrm{aB}$ & $616 \mathrm{aA}$ & $117 \mathrm{cA}$ & $276 \mathrm{bA}$ \\
BRS 7 & $130 \mathrm{bcA}$ & $117 \mathrm{bA}$ & $243 \mathrm{bA}$ &
\end{tabular}

Lowercase letters compare genotypes per stage and cold duration. Uppercase letters compare cold temperature durations per genotype and stage. *Indicates difference between stages per genotype and cold duration. ${ }^{1 / N o}$ tillers were evaluated in the treatment. 
both at microsporogenesis and anthesis (Table 3), with the exception of IRGA 417 at anthesis, whose reductions were not increased by longer exposure to cold.

\section{Percentage of reduction in spikelet fertility}

Anthesis was the most sensitive stage to cold when cold tolerance was measured as the reduction in spikelet fertility (Table 4). With three days of cold exposure there was no difference between the stages of development, with the exception of Diamante, which was more affected at anthesis. From five days of exposure on, the majority of genotypes presented the highest reduction in spikelet fertility at anthesis, except for BRS 7 and Quilla 64117.

At both stages, the cold sensitive genotypes BRS 7, IRGA 417 and IR 8 presented the highest reduction in spikelet fertility due to cold (Table 4). At microsporogenesis, Diamante was the genotype with the lowest reduction in spikelet fertility with ten days of cold exposure, but at anthesis Quilla 64117 was the least affected with seven and ten days of cold exposure (Table 4).

The influence of duration of cold exposure on the reduction of spikelet fertility in both stages depended on the genotype, although only after seven days of cold exposure it was possible to differentiate the Japonica cold tolerant genotypes from the Indica cold sensitive ones (Table 4).

\section{Panicle exsertion and spikelet fertility as a function of cold temperature duration}

Regression analysis for panicle exsertion showed that, except for Quilla 64117, all genotypes experienced significant linear reductions in panicle exsertion as cold temperature duration increased at anthesis (Table 5). At microsporogenesis, linear regression was significant only for the genotypes IR 8 , BRS 7 and Diamante, but according to the coefficient of determination it only explained most the variation in the response for IR 8 (Table 5).

The linear regression for spikelet fertility as a function of duration of cold exposure was significant for all the genotypes, at both reproductive stages, with the exception of Quilla 64117 at anthesis (Table 5), indicating that the higher the cold duration, the higher the decrease in spikelet fertility. From the coefficients of determination it follows that at anthesis the model explained most of the variation of spikelet fertility in all genotypes in which it was significant except Quilla 64117, which did not happen at microsporogenesis.

\section{DISCUSSION}

In the present study cold tolerance was expressed as percentage of reduction in panicle exsertion and in spikelet fertility due to cold in relation to the control, which allows for evaluating cold tolerance per se and not only the trait under stress (Datta \& Siddiq, 1983). In a study where spikelet fertility was divided

Table 4 - Means for percentage of reduction in spikelet fertility of six rice genotypes submitted to four cold temperature $\left(17^{\circ} \mathrm{C}\right)$ durations at two stages of the reproductive period.

\begin{tabular}{|c|c|c|c|c|}
\hline \multirow{2}{*}{ Genotype } & \multicolumn{4}{|c|}{ Microsporogenesis } \\
\hline & 3 days & 5 days & 7 days & 10 days \\
\hline Quilla64117 & $0 \mathrm{aC}$ & $-{ }^{1 /}$ & $14 \mathrm{cB}$ & $27 \mathrm{bA}^{*}$ \\
\hline Quilla66304 & $18 \mathrm{bA}$ & - & $2 \mathrm{cB}^{*}$ & $19 \mathrm{cA}^{*}$ \\
\hline Diamante & $1 \mathrm{dA}^{*}$ & $2 \mathrm{aA}^{*}$ & $7 \mathrm{cA}^{*}$ & $6 \mathrm{cA}^{*}$ \\
\hline IR 8 & $21 \mathrm{cC}$ & $37 \mathrm{bB} *$ & $83 \mathrm{abA}$ & $89 \mathrm{aA}^{*}$ \\
\hline IRGA 417 & $42 \mathrm{cdC}$ & $48 \mathrm{bC} *$ & $70 \mathrm{bB} *$ & $93 \mathrm{aA}^{*}$ \\
\hline BRS 7 & $72 \mathrm{~dB}$ & $92 \mathrm{cA}$ & $95 \mathrm{aA}$ & 99 aA \\
\hline \multirow[t]{2}{*}{ Genotype } & \multicolumn{4}{|c|}{ Anthesis } \\
\hline & 3 days & 5 days & 7 days & 10 days \\
\hline Quilla64117 & $5 \mathrm{aA}$ & - & $11 \mathrm{dA}$ & $7 \mathrm{cA}$ \\
\hline Quilla66304 & $7 \mathrm{bC}$ & $55 \mathrm{bB}$ & $51 \mathrm{cB}$ & $80 \mathrm{bA}$ \\
\hline Diamante & $16 \mathrm{cC}$ & $27 \mathrm{aC}$ & $48 \mathrm{cB}$ & $80 \mathrm{bA}$ \\
\hline IR 8 & $18 \mathrm{cD}$ & $66 \mathrm{bcC}$ & $87 \mathrm{bB}$ & $100 \mathrm{aA}$ \\
\hline IRGA 417 & $44 \mathrm{cdC}$ & $76 \mathrm{cB}$ & 99 aA & $100 \mathrm{aA}$ \\
\hline BRS 7 & $66 \mathrm{~dB}$ & $96 \mathrm{dA}$ & $99 \mathrm{aA}$ & $100 \mathrm{aA}$ \\
\hline
\end{tabular}

Lowercase letters compare genotypes per stage and cold duration. Uppercase letters compare cold temperature durations per genotype and stage. *Indicates difference between stages per genotype and cold duration. ${ }^{1 /}$ No tillers were evaluated in the treatment. 
Table 5 - Regression equations estimated for panicle exsertion $(\mathrm{cm})$ and spikelet fertility $(\%)$ as a function of cold temperature duration for each genotype and stage of the reproductive period.

\begin{tabular}{lcccc}
\hline \multirow{2}{*}{ Panicle exsertion $(\mathrm{cm})$} & \multicolumn{2}{c}{ Microsporogenesis } & \multicolumn{2}{c}{ Anthesis } \\
\cline { 2 - 5 } & Equation & $\mathrm{R}^{2}$ & Equation & $\mathrm{R}^{2}$ \\
\hline Quilla 64117 & - & - & - & - \\
Quilla 66304 & - & - & $\mathrm{y}=4.4-1.8 \mathrm{x}^{*}$ & 0.67 \\
Diamante & $\mathrm{y}=3.4-0.6 \mathrm{x}^{*}$ & 0.26 & $\mathrm{y}=2.7-1.5 \mathrm{x}^{*}$ & 0.65 \\
IR 8 & $\mathrm{y}=1.6-2.7 \mathrm{x}^{*}$ & 0.90 & $\mathrm{y}=0.6-3.1 \mathrm{x}^{*}$ & 0.77 \\
IRGA 417 & - & - & $\mathrm{y}=-4.2-1.1 \mathrm{x}^{*}$ & 0.63 \\
BRS 7 & $\mathrm{y}=-1.8-0.8 \mathrm{x}^{*}$ & 0.28 & $\mathrm{y}=-3.7-1.8 \mathrm{x}^{*}$ & 0.57 \\
\hline Spikelet fertility (\%) & \multicolumn{2}{c}{ Microsporogenesis } & \multicolumn{2}{c}{ Anthesis } \\
\multicolumn{2}{c}{ Equation } & $\mathrm{R}^{2}$ & Equation & $\mathrm{R}^{2}$ \\
\hline Quilla 64117 & $\mathrm{y}=96.0-5.7 \mathrm{x}^{*}$ & 0.78 & & - \\
Quilla 66304 & $\mathrm{y}=83.2-2.6 \mathrm{x}^{*}$ & 0.19 & $\mathrm{y}=85.7-16.5 \mathrm{x}^{*}$ & 0.89 \\
Diamante & $\mathrm{y}=95.9-1.5 \mathrm{x}^{*}$ & 0.32 & $\mathrm{y}=97.5-17.6 \mathrm{x}^{*}$ & 0.93 \\
IR 8 & $\mathrm{y}=87.8-19.6 \mathrm{x}^{*}$ & 0.91 & $\mathrm{y}=86.4-23.2 \mathrm{x}^{*}$ & 0.96 \\
IRGA 417 & $\mathrm{y}=87.5-20.1 \mathrm{x}^{*}$ & 0.95 & $\mathrm{y}=84.5-24.2 \mathrm{x}^{*}$ & 0.94 \\
BRS 7 & $\mathrm{y}=51.4-14.6 \mathrm{x}^{*}$ & 0.61 & $\mathrm{y}=60.9-19.8 \mathrm{x}^{*}$ & 0.79 \\
\hline
\end{tabular}

*Significant $(P<0.05)$. - Non-significant equations.

into four components, Satake \& Shibata (1992) found that the genotypes differed in relation to some components, as number of pollen grains, even in the absence of cold. With the procedure employed in this study, of quantifying the amount of reduction in each trait due to cold in relation to the control temperature, interpretation errors caused by the genotype's intrinsic factors were minimized and they were compared under the same criteria.

Evaluation of these traits in the present study indicated that the temperature of $17^{\circ} \mathrm{C}$ for only three days was already capable of causing damage to the plants and this damage varied according to the genotype and reproductive stage. It is known that temperature is an important factor in determining greater or lower damage to plants. Studies under controlled temperature have used variable temperature between day and night (Lin \& Peterson, 1975; Gunawardena et al., 2003 ) or constant temperature, which has varied from 10 to $20^{\circ} \mathrm{C}$ (Lin \& Peterson, 1975; Lee, 1979; Khan et al., 1986; Andaya \& Mackill, 2003). In choosing the temperature for performing these evaluations, it is important to consider that lower temperatures allow for the identification of highest levels of tolerance and high temperatures help identify moderate tolerance. It has been reported that temperatures between 15 and $17^{\circ} \mathrm{C}$ are critical for cold tolerant genotypes and between 17 and $19^{\circ} \mathrm{C}$ for cold sensitive ones (Nishiyama et al., 1969 apud Terres, 1991). For this reason the choice was for $17^{\circ} \mathrm{C}$ as the cold temperature for the tests reported herein, and the different levels of stress were given by the variation in the duration of exposure to this temperature.
In all durations of cold exposure and stages tested, Indica genotypes were more sensitive than Japonica, when cold tolerance was evaluated by means of percentage of reduction in spikelet fertility. This was already expected, since the Japonica subspecies is generally considered more cold tolerant than Indica (Saito et al., 2004). With regard to the percentage of reduction in panicle exsertion however, subspecies separation was not clear in any of the stages and cold durations (Table 3). The two traits evaluated were not correlated during microsporogenesis, but showed a significant moderate correlation at anthesis $\left(0.35^{* *}\right)$. The data suggest that the percentage of reduction in spikelet fertility is a more reliable way of evaluating cold tolerance in the genotypes studied. Damage caused by cold temperature in panicle exsertion and spikelet fertility may have distinct physiological bases, because while decreases in exsertion are a result of the effects on celular division and elongation, decreases in fertility result from damage during pollen grain formation and germination. Thus, these differences may explain the lack of distinction among the tolerant and sensitive genotypes when evaluated by panicle exsertion in relation with what was observed for spikelet fertility, where good distinction was possible.

Considering the percentage of reduction in spikelet fertility, the largest reductions occurred when cold was applied at anthesis, indicating that cold sensitivity was higher at this stage (Tables 4 and 5). Among the cold tolerant genotypes this was even more evident, because despite being superior to the sensitive ones at both stages, their degree of tolerance was higher at the microsporogenesis stage (Tables 4 and 5). These results 
were unexpected since rice is considered more sensitive to cold at microsporogensis than at anthesis (Lin \& Peterson, 1975; Nishiyama, 1984). Considering that the maximum microsporogenesis occurs at some point between the interval -3 to $10 \mathrm{~cm}$ and this interval was represented for each genotype, it may be concluded that microsporogenesis was misidentified when compared to anthesis. This may also suggest that the longest cold durations affected the panicles at anthesis more uniformily than at microsporogenesis, leading to the higher cold sensitivity for anthesis. Significant correlations were found, however, between microsporogenesis and anthesis for the percentage of reduction in panicle exsertion $\left(0.78^{* *}\right)$ and for percentage of reduction in spikelet fertility $(0.74 * *)$, suggesting that selection for cold tolerance is possible by subjecting plants to cold in only one stage. In this case, anthesis would be better because besides being more sensitive to the temperature of $17^{\circ} \mathrm{C}$ for the two traits evaluated, its determination is easier and more precise, regardless of genotype. Lee (1979), also reported high correlation between anthesis and microsporogenesis with regard to spikelet fertility and recommended anthesis for the evaluation of rice cold tolerance.

Besides the stage in which the plant is to be evaluated, duration of exposure to cold is also important, because it defines the degree of stress that will be imposed. According to Bertin et al. (1996), shorter periods allow for the detection of genotypes that are more sensitive and longer periods favors tolerant genotypes. For the genotypes evaluated in this study, a minimum of seven days was necessary to distinguish tolerant from sensitive, at both stages, based on reduction in spikelet fertility. In the present study exposing rice genotypes to the temperature of $17^{\circ} \mathrm{C}$ for seven days at the anthesis stage allowed for the distinction between cold tolerant and cold sensitive genotypes in terms of percentage of reduction in spikelet fertility. This method may be useful if precise evaluations of potential parents as well as segregating generations of a breeding program for cold tolerance at the reproductive period are needed.

\section{REFERENCES}

ALVARADO, J.R.; GRAU, P.B. Mejoramiento del arroz en Chile por tolerancia a frío. In: REUNIÓN SOBRE MEJORAMIENTO DE ARROZ EN EL CONO SUR, 1991, Goiânia. Trabajos. Montevideo: IICA - PROCISUR, 1991. p.105-114. (Diálogo, 33).

ANDAYA, V.C.; MACKILL, D.J. QTLs conferring cold tolerance at the booting stage of rice using recombinant inbred lines from a japonica $\mathrm{x}$ indica cross. Theoretical and Applied Genetics, v.106, p.1084-1090, 2003.

BERTIN, P.; KINET, J.M.; BOUHARMONT, J. Evaluation of chilling sensitivity in different rice varieties. Relationship between screening procedures applied during germination and vegetative growth. Euphytica, v.89, p.201-210, 1996.
DATTA, D.; SIDDIQ, E.A. Genetic analysis of cold tolerance at seedling phase in rice. Indian Journal of Genetics and Plant Breeding, v.43, p.345-349, 1983.

FUTSUHARA, Y.; KIKUCHI, F. Gene analysis for agronomic traits. In: TSUNODA, S.; TAKAHASHI, N. (Ed.) Biology of rice. Tokyo: Japanese Science Society Press, 1984. p.275-291.

GUNAWARDENA, T.A.; FUKAI, S.; BLAMEY, F.P.C. Low temperature induced spiklet sterility in rice. I. Nitrogen fertilization and sensitive reproductive period. Australian Journal of Agricultural Research, v.54, p.937-946, 2003.

GUORUI, Z. Advances in research on cold tolerance in rice. Jiangsu Journal of Agricultural Sciences, v.7, p.52-56, 1991.

KHAN, D.R.; MACKILL, D.J.; VERGARA, B.S. Selection for tolerance to low temperature-induced spikelet sterility at anthesis in rice. Crop Science, v.26, p.694-698, 1986.

LEE, J.H. Screening methods for cold tolerance at Crop Experiment Station Phytotron and at Chuncheon. In: RICE COLD TOLERANCE WORKSHOP, Los Baños, 1979. Report. Los Baños: International Rice Research Institute, 1979. p.77-90.

LIN, S.S.; PETERSON, M.L. Low temperatue-induced floret sterility in rice. Crop Science, v.15, p.657-660, 1975.

McKENZIE, K.S.; JOHNSON, C.W.; TSENG, S.T.; OSTER, J.J.; BRANDON, D.M. Breeding improved rice cultivars for temperate regions: a case study. Australian Journal of Experimental Agriculture, v.34, p.897-905, 1994.

NISHIYAMA, I. Climatic influence on pollen formation and fertilization. In: TSUNODA, S.; TAKAHASHI, N. (Ed.) Biology of rice. Tokyo: Japan Scientific Societies Press, 1984. p.153-171.

SAITO, K.; MIURA, K.; NAGANO, K.; HAYANO-SAITO, Y.; ARAKI, H.; KATO, A. Identification of two closely linked quantitative trait loci for cold tolerance on chromosome 4 of rice and their association with anther length. Theoretical and Applied Genetics, v.103, p.862$868,2001$.

SAITO, K.; MIURA, K.; HAYANO-SAITO, Y.; KATO, A. Analysis of quantitative trait loci for cold tolerance at the booting stage of rice. Jarq, v.37, p.1-5, 2003.

SAITO, K.; HAYANO-SAITO, Y.; MARUYAMA-FUNATSUKI, W.; SATO, Y.; KATO, A. Physical mapping and putative candidate gene identification of a quantitative trait locus $C t b 1$ for cold tolerance at the booting stage of rice. Theoretical and Applied Genetics, v.109, p. 515-522, 2004.

SAS Institute. System for information. Version 8.0. Cary: Statistical Analysis System Institute, 2000.

SATAKE, T.; SHIBATA, M. Male sterility caused by cooling treatment at the young microspore stage in rice plants. XXXI. Four components participating in fertilization. Japanese Journal of Crop Science, v.61, p.454-462, 1992.

TAKEUCHI, Y.; HAYASAKA, H.; CHIBA, B.; TANAKA, I.; SHIMANO, T.; YAMAGISHI, M.; NAGANO K.; SASAKI, T.; YANO, M. Mapping quantitative trait loci controlling cooltemperature tolerance at booting stage in temperate Japonica rice. Breeding Science, v.51, p.191-197, 2001.

TERRES, A.L. Melhoramento de arroz irrigado para tolerância ao frio no Rio Grande do Sul - Brasil. In: REUNIÓN SOBRE MEJORAMIENTO DE ARROZ EN EL CONO SUR, Goiânia, 1991. Trabajos. Montevideo: IICA - PROCISUR, 1991. p.91-103. (Diálogo, 33).

TERRES, A.L.; GALLI, J. Efeitos do frio em cultivares de arroz irrigado no Rio Grande do Sul - 1984. In: EMPRESA BRASILEIRA DE PESQUISA AGROPECUÁRIA. Fundamentos para a cultura do arroz irrigado. Campinas: Fundação Cargill, EMBRAPA, CPATB, 1985. p.83-94.

TILQUIN, J.P.; DETRY, F. Efficiency of natural selection against coldinduced sterility in bulked families. International Rice Research Notes, v.18, p.33, 1993.

YOSHIDA, S. Fundamentals of rice crop science. Los Baños: International Rice Research Institute, 1981. cap.1, p.1-63: Growth and development of the rice plant.

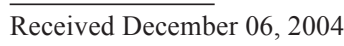

Accepted April , 2006 